\title{
GLOBALIZACCÃO ECONÔMICA, POLÍTICAS PÚBLICAS E EXCLUSÃO SOCIAL
}

David Ferreira Carvalho*

\section{Introdução}

Antes de mais nada, é preciso informar que este paper foi preparado para uma palestra, no Encontro sobre Políticas Públicas e Educação Social, coordenado pela UFPA e SETEP-Pa., e portanto, não apresenta o rigor dos trabalhos acadêmicos no que tange às referências bibliográficas. No final do texto, entretanto, segue a bibliografia consultada que inspirou o presente trabalho. Este ensaio foi organizado em cinco seções, além desta introdução. $\mathrm{Na}$ primeira discutem-se os impactos da globalização econômica no mercado de trabalho; na segunda apresentam-se os problemas que as inovações tecnológicas podem provocar no mercado de trabalho; na terceira especulam-se alguns processos de difusão tecnológica dos complexos eletroeletrônicos e da biotecnologia; na quarta seção, discutem-se sobre as possibilidades do aumento do desemprego e as alternativas com base no terceiro setor; por fim, na quinta seção,

\footnotetext{
* Doutor em Economia pela Universidade de Campinas - UNICAMP e Coordenador do Mestrado em Planejamento do Desenvolvimento - PLADES/NAEA da Universidade Federal do Pará - UFPA.
} 
analisam-se os paradoxos da globalização tecnológica e especulam-se sobre o futuro do capitalismo.

Começo esta palestra dizendo: "o desenvolvimento humano é o fim, o crescimento econômico um meio". Ou seja, a equação do desenvolvimento sustentável é dada por: desenvolvimento é igual a eficiência econômica (crescimento sustentado e tecnologia) mais equidade social (distribuição de renda e da riqueza) e mais preservação sócioambiental (proteção sócio-ecológica do homem e da natureza). Dado o tema que me foi solicitado para desenvolver aqui, não irei abordar o terceiro termo da equação social.

De início deve-se dizer que o crescimento econômico tem como objetivo, em última instância, o enriquecimento de bens materiais e serviços às vidas das pessoas. Porém, não há uma ligação automática entre crescimento econômico, desenvolvimento econômico e desenvolvimento humano. E, mesmo quando essas ligações são estabelecidas, as mesmas podem gradualmente ser corroídas - a não ser que sejam fortalecidas regularmente através da gestão de um aparato de políticas públicas socialmente inteligentes, capazes de compatibilizar a eficiência econômica (através do mercado) com a eqüidade social (pela via do governo).

Neste final de século, há duas descobertas perturbadoras: (1) o crescimento econômico tem diminuído muito, nos últimos 15 anos, em cerca de mais 100 países com quase um quarto da população mundial; (2) as ligações entre crescimento e desenvolvimento humano têm fracassado para muitas pessoas e países, com desenvolvimento desequilibrado, vale dizer com bom crescimento econômico, mas fraco desenvolvimento humano ou com bom desenvolvimento humano, mas fraco crescimento econômico. De fato, desde 1980, a estagnação sócio-econômica afetou mais de 100 países reduzindo o rendimento de 1,6 milhão de pessoas.

O mundo tornou-se mais polarizado, e a separação entre pobres e ricos foi ampliada. De fato, em 1993, dos 23 bilhões de dólares do PIB mundial, 18 bilhões eram dos países industrializados $(78,0 \%)$ e apenas 5 bilhões dos países em desenvolvimento (22\%), apesar destes terem $80 \%$ da população mundial. Os $20 \%$ dos países mais pobres viram a sua parte do rendimento global cair de 2,3\% para 1,4\% nos últimos 30 anos. Enquanto isso, a parte dos $20 \%$ mais ricos aumentou de $70 \%$ para $80 \%$. Isso duplicou o "gap" entre as partes numa proporção de 30: 1 para 61: 1. Mais ainda, os ativos reais dos 358 milionários do mundo excedem, hoje, os rendimentos 
de $45 \%$ da população mundial. O hiato do rendimento per capita entre os países industrializados e em desenvolvimento triplicou de 5.700 dólares para 15.400 dólares.

Os políticos e tecnocratas ficam, muitas vezes, deslumbrados com as altas taxas de crescimento do produto econômico de alguns países, porém, embora estas sejam importantes, eles precisam preocupar-se também com a distribuição desse produto e da riqueza na estrutura social e com a qualidade de vida das populações, sobretudo das mais carentes. A não ser que os governos desenvolvam ações corretivas e oportunas para evitar a exclusão social generalizada, o crescimento econômico pode se tornar desequilibrado e imperfeito socialmente em termos de geração de emprego, desumano, sem direito a opinião, desenraizado industrialmente e sem futuro promissor.

Em suma, o desenvolvimento que perpetua as desigualdades atuais não é sustentável e nem parece ser sustentado. No Brasil, em 1993, a renda per capita era de 5.370 dólares e a renda per capita dos $20 \%$ mais pobres de 564 dólares-medida em termos de paridade de poder de compra (PPC).

\section{Globalização econômica e mercado de trabalho}

A globalização é como o elefante da parábola indiana, segunda a qual doze cegos estavam pegando, cada um, uma parte do elefante - a cauda, a tromba, as presas, as pernas, as orelhas, as costas e cada um deles achava que estava tocando um animal diferente e, quando relatavam o que sentiam, descreviam animais muito diferentes. Conclusão: o verdadeiro elefante nunca surge da análise superficial. $O$ futuro da globalização para o homem moderno é como o mapa de Colombo em que metade do território estava assinalada com a frase "terra desconhecida".

Lester Thurow, com o seu clássico "O futuro do capitalismo", usa da metáfora das cinco placas tectônicas da geologia para explicar o movimento do capitalismo contemporâneo: (1) o fim do comunismo; (2) a mudança do padrão tecnológico baseada em indústrias de poder cerebral feito pelo homem que não possuem lugares naturais predeterminados; (3) a população mundial crescendo, mudando de lugar e envelhecendo; (4) uma economia global em que tudo pode ser produzido e comercializado em qualquer parte do mundo, com poder de compra; e (5) uma era sem uma hegemonia absoluta. 
$\mathrm{Na}$ década de 60, a economia mundial cresceu a uma taxa de 5,0\% a.a.; nos anos 70, esse crescimento caiu para 3,6\%; nos anos 80, para 2,0\% e, até a primeira metade dos anos 90 , para 2,0\% a.a. Até o começo dos anos 90, o México era o exemplo típico de país emergente que deveria ser seguido. Mas logo o seu presidente Salinas caiu desmoralizado, e o México amargou a bancarrota. Depois foram os tigres asiáticos e agora até mesmo o poderoso Japão.

O desemprego global atingiu seu mais alto nível, neste final de século, desde a grande depressão da década de 30. No presente, sabe-se que na economia mundial existem mais de 800 milhões de desempregados ou subempregados. Este número deverá crescer, até o final do século XX, devido à tendência da revolução tecnológica para aumentar o desemprego estrutural.

A maciça substituição do homem pela máquina forçará as nações a repensar o papel a ser desempenhado pelos seres humanos no processo social. Mas, por enquanto, apesar da globalização econômica, e do aumento dos lucros, as empresas transnacionais continuam anunciando demissões em massa. Nos EUA, as empresas, em janeiro de 1994, demitiram 108 mil trabalhadores. A maior parte das demissões está ocorrendo como conseqüência da reengenharia nas indústrias de serviços - em que a reestruturação administrativa e a introdução de novas tecnologias de racionalização do trabalho, estão gerando maior produtividade, maiores lucros e menos emprego.

As empresas estão reestruturando suas organizações, tornando-as computer friendly - amistosas ao computador. Com isso, estão sendo eliminados os níveis de gerência tradicionais, comprimindo-se as categorias de determinados cargos de supervisão, criando-se novas equipes de trabalho, treinando-se funcionários em várias habilidades, reduzindo-se e simplificando os processos de produção e distribuição e dinamizando-se a administração.

Michael Hammer, ex-professor do MIT e pioneiro na reestruturação de ambiente de trabalho, diz que a reengenharia resulta na perda de mais de $40 \%$ dos empregos numa empresa e pode levar à redução de até $70 \%$ dos funcionários. Hammer estima que nos dias de hoje até $80 \%$ das pessoas envolvidas em funções de gerência intermediária estão sujeitas à demissão.

Nos EUA, segundo o The Wall Street Journal, a reengenharia corporativa pode eliminar de 1 a 2,5 milhões de empregos por ano. No futuro, esta perda pode chegar a 25 milhões de emprego da força de trabalho que hoje está na 
casa dos 90 milhões. Há quem suponha que "as máquinas serão o proletariado do futuro".

O ritmo acelerado da automação e da reengenharia estão levando a economia global à era da fábrica sem trabalhadores: entre 1981 a 1993, nos EUA, desapareceu mais 1,8 milhão de empregos. Na Alemanha, no ano de 1992, foram eliminados 500 mil empregos. Nos EUA, o número de empregos caiu de $30 \%$ para $17 \%$ e logo chegará a $12 \%$.

A medida em que o desemprego aumenta, os economistas vão mudando os conceitos de pleno emprego: Nos anos 50, a média do desemprego aceitável para aquela década ficou em 3,0\%; nos anos 60, subiu para 4,0\%; nos 80 este nível passou para 5,5\%; agora, na década de 90, o atual nível de 6,0\% tende a aumentar para mais de $8 \%$. Jeremy Rifkin, em seu clássico "O Fim dos Empregos (declínio dos níveis de emprego e redução da força de trabalho global)", afirma que as novas tecnologias de informática e comunicação estão, finalmente, causando seus impactos perversos no mercado de trabalho. A automatização das atividades produtivas, na agricultura, indústria e serviços, está substituindo o homem pela máquina.

Redefinir as novas oportunidades e responsabilidades de emprego para milhões de pessoas, sem o emprego de massa formal, deverá ser a grande questão social do século XXI. As novas tecnologias são uma força poderosa que tem potencial tanto para libertar a humanidade para uma vida de mais lazer quanto para desequilibrar o mercado de trabalho.

\section{Inovações tecnológicas e seus efeitos no mercado de trabalho}

\subsection{O Novo Paradigma Tecnológico e a Nova Realidade Social}

Mais lazer para o povo ou mais lucro? Eis o dilema da tecnologia global. Marx sabia disso. O argumento da "mágica da tecnologia" baseiase na Lei de Say que diz que "a oferta cria sua própria procura". Assim, no mesmo instante que um produto é criado, também é gestado um mercado para outros produtos na dimensão de seu próprio valor. Esse argumento, apropriado pelos economistas neoclássicos, passou a admitir que as novas tecnologias de racionalização do trabalho aumentavam a produtividade permitindo que os fornecedores produzissem mais bens a um custo menor por unidade. A oferta de produtos mais baratos, cria a sua própria demanda. Demanda maior estimula a produção num círculo vicioso. 
Contra este argumento, surgiu o princípio da demanda efetiva de Marx, Keynes e Kalecki. Para estes, são os gastos efetivos, sobretudo em consumo e investimento, que determinam o emprego efetivo e a renda agregada, e não ao contrário. Portanto, numa economia mercantilmonetária, como é a economia capitalista, a moeda não é neutra porque a preferência pela liquidez compete com os investimentos produtivos na tomada de decisões por parte dos agentes econômicos num mundo onde a incertez̧a leva a inquietudes e (des) confianças que só são atenuadas pelas convenções.

Pela lógica da racionalidade econômica do mainstream, mesmo que trabalhadores sejam deslocados pela tecnologia, o problema do desemprego estrutural seria resolvido porque um número crescente de trabalhadores desempregados forçará a redução dos salários reais. Assim, a flexibilidade do mercado de trabalho para níveis de salários menores incita os empregadores a contratar mais trabalhadores ao invés de investir em equipamentos mais caros, amenizando o desemprego tecnológico. A função social do exército industrial de reserva e da superpopulação relativa de Marx, por outro lado, encarrega-se da dinâmica do mercado sempre que houver escassez de mão-de-obra no mercado de trabalho.

\subsection{O Marketing e o nascimento do consumidor insatisfeito}

A crise dos anos 20, que se manifestou com a queda do nível de consumo nos EUA, forçou os meios de comunicação da época a desenvolverem o que ficou conhecido como o "Evangelho do Consumo de Massa" - a propaganda. Assim, a propaganda de massa moldou, no imaginário coletivo da classe trabalhadora, a maior revolução sócio-cultural da época, que foi a mudança do padrão de consumo de base artesanal e comunitária para o consumo de massa: incutiu-se a substituição da psicologia da parcimônia para a psicologia do consumo perdulário, assim surgiu o consumidor insatisfeito.

O marketing, que até então havia desempenhado um papel secundário nos negócios, assumiu grande importância ao mudar a cultura do produtor pela do consumidor compulsivo. O novo padrão de consumo redefiniu assim um novo status e a diferenciação social ou exclusão social. Transformar o trabalhador num consumidor preocupado com o status foi um empreendimento radical. Para isso era preciso denegrir os produtos caseiros e promover as lojas e os fabricados. O principal alvo foram os jovens. Para facilitar as compras, inventou-se o crédito ao consumidor. Mesmo assim, a crise não foi resolvida. 
Em dezembro de 1929, havia 1 milhão de desempregados nos EUA. Em 1935, esse número subiu para 15 milhões. Os líderes sindicais, então, propuseram a trabalho compartilhado. Essa proposta consistiu na redução da jornada de trabalho para 30 horas semanais. Isto significou que a comunidade econômica dividiria os ganhos de produtividade com seus trabalhadores na forma de horas de trabalho reduzidas. No entanto, os empresários não toparam porque ficaram com medo da institucionalização permanente, pelas leis americanas, da jornada de trabalho. Essa idéia do trabalho compartilhado foi materializada na lei de BLACK (o senador Hugo L. Black) e chegou a ser aprovada pelo senado, porém foi vetada pelo Presidente Roosevelt.

H. I. Harrimam, Presidente da Câmara do Comércio Nacional, disse: "É melhor que todos nós estejamos trabalhando uma parte do tempo, do que alguns estarem no trabalho o tempo todo, enquanto outros não terem qualquer trabalho". Bertrand Russell, o grande filósofo e matemático inglês, disse: "Não deveria haver 8 horas de trabalho para alguns e zero para outros, mas quatro horas diárias para todos". O único antídoto para o desemprego estrutural é o aumento da demanda efetiva.

Com o fracasso da "vangelização do consumo", como resultado do colapso do crédito ao consumidor e do aborto do trabalho compartilhado, os EUA acabaram recorrendo ao NEW DEAL - com os programas de construção civil, agricultura, de desenvolvimento regional, de auxílio-desemprego e de apoio as organizações sindicais nas negociações salariais com os grandes oligopólios - mas foi a II guerra mundial que salvou o país.

\subsection{A terceira revolução industrial e o mercado do trabalho}

Com o fim da guerra fria, o complexo industrial-bélico e os gastos com o Estado do bem estar social foram desativados. No presente, a onda da terceira revolução industrial não aponta ainda para solução do desemprego global. De fato, no passado, quando uma revolução tecnológica ameaçava a perda de emprego em massa em determinado setor econômico, um novo surgia para absorver a mão-de-obra excedente. A segunda revolução industrial permitiu que a indústria urbana e os complexos agroindustriais absorvessem milhões de trabalhadores expulsos do campo pela revolução verde. 
No entanto, nos dias atuais, na medida em que todos os setores vão se reestruturando e se automatizando, não se consegue ver nenhum setor econômico significativo, nem mesmo o complexo eletroeletrônico e a biotecnologia, com potencial suficiente para absorver milhões de trabalhadores demitidos.

Aliás, o único setor no horizonte é o do conhecimento - um grupo de indústrias e de especialistas de elite que serão responsáveis pela nova economia industrial auto matizada e de alta tecnologia. Os novos profissionais - os analistas simbólicos ou trabalhadores do conhecimento - vêm das áreas da ciência, engenharia, administração, consultoria, ensino, marketing, multimídia e lazer. Porém, mesmo que esse setor continue a crescer, permanecerá insignificante se comparado à grande massa de trabalhadores que serão deslocados pela nova geração das "máquinas inteligentes".

Os bons empregos disponíveis estão no setor de conhecimento e informação. É ingenuidade pensar que grandes massas de trabalhadores sem qualificação ou semi-qualificados possam ser treinadas, "da noite para o dia", para tornarem-se físicos, cientistas da computação, tecnólogos de alto nível, biólogos moleculares etc. Portanto, os programas de treinamento, embora necessários, não conseguirão tirar de uma hora para outra o atraso educacional secular dos países emergentes. Mesmo nos EUA, o estudo sobre a alfabetização adulta na América, feita pelo Departamento do trabalho, mostra que o nível de instrução de mais de 90 milhões dos americanos é tão fraco que sequer sabem usar a calculadora para realizar uma simples diferença entre o preço de liquidação e o preço normal de um bem no supermercado.

Ainda que a reeducação e o retreinamento fossem implantados em escala maciça não haveria disponibilidade suficiente de emprego no setor de alta tecnologia para absorver o grande número de demitidos pelo novo padrão tecnológico. Pior ainda, hoje, com o enfraquecimento do setor público, a alternativa keynesiana é pouco atraente.

\subsection{A fragilidade do setor público frente ao desemprego estrutural}

Nos anos 50 e 60, os gastos crescentes dos governos, na maioria dos países capitalistas, foram os únicos meios viáveis para superar o problema da demanda insuficiente. Sempre que havia alto grau de capacidade ociosa na indústria, o governo contra-atacava com políticas 
anticíclicas keynesianas. $\mathrm{Na}$ verdade, o aumento do desemprego tecnológico e a demanda ineficaz têm conduzido a economia capitalista e não a Lei de Say. No caso dos gastos públicos, estes têm diminuído nos últimos 30 anos. O número de funcionários públicos deverá ser reduzido mais ainda na medida em que os governos federal, estadual e municipal diminuírem suas operações de gastos públicos e automatizarem os seus serviços. A reengenharia no governo, utilizando práticas gerenciais, embora positiva do ponto de vista da eficiência, pode aumentar o desemprego público. Nos EUA, a meta é eliminar 252 mil funcionários públicos da esfera federal para economizar 108 bilhões de dólares. No Brasil, o ajuste fiscal e a Lei Camata, que estabelece um teto de $60 \%$ da receita correntes líquidas para despesas com pessoal, irão aumentar o número de demitidos.

\section{A globalização do novo paradigma tecnológico}

\subsection{A utopia tecnológica e o culto a eficiência}

Cada sociedade cria uma imagem idealizada do futuro - uma visão utópica que serve de guia para conduzir a imaginação e a energia de seu povo. Este foi o caso de Moisés que prometeu a Canaã, a terra prometida de muito leite e mel. Hoje, num mundo globalizado, a visão tecno-utópica tem sido um instrumento de sedução de dirigentes políticos e gerentes de empresas. Em 1886, a eletricidade iluminou as primeiras lojas de New York. No momento, com o avanço tecnológico da automação, da informática e das telecomunicações, o efeito hipnotizante das novidades da indústria eletroeletrônica - vídeos, cassetes, TVAs vídeo-games, TVs em cores de rede, TVs a cabo, telefone celular, gravadores, tradutores eletrônicos, computadores multimídias pentium, scanners, fax, projetores data show, etc. - está criando a cultura da tecnoeletrônica no sentido de que os homens estão se transformando em robots mecatrônicos na sua forma de pensar (lógica digital), de amar (namoro pela Internet), bem como nos movimentos motores de suas mãos. A numerologia natural de 9 algarismos ou decimal de 10, com o zero, ficou reduzida a dois: 0 e 1.

Os utopistas tecnólogos, desde Flash Gordon até o famoso filme Guerra nas Estrelas, caricaturado por Spieberg, têm imaginado o éden do futuro, criado pela tecnologia. Lippmann diz que o novo Moisés que levaria o seu povo para a terra prometida não seria um homem de Deus mas um homem da ciência. 
O culto à eficiência passou a ser a nova palavra de ordem. Foi Frederick W Taylor que popularizou este conceito. A tecnocracia substituirá os acionistas, antecipou Kenneth Galbrait em seu livro: “O novo estado industrial". As escolas de administração pública foram criadas para formar gerentes profissionais de forma a tornar os governos mais científicos e mais eficientes. A escola pública também tem de sujeitar-se ao teste da eficiência, tal como no mercado. Mesmo no lar a eficiência chegou. Mas, para que serve todo esse progresso técnico se não há progresso social no sentido de mais emprego e melhoria de renda da maioria da humanidade. A exclusão social dos desempregados e subempregados e a precariedade do trabalho dos empregados que ganham pouco limitam o aproveitamento dos benefícios do desenvolvimento das forças produtivas capitalistas a uma fração privilegiada da população.

\subsection{O complexo eletroeletrônico e a última fronteira da alta tecnolagia}

A transição para uma sociedade quase sem trabalhadores, a sociedade da informação, é o terceiro e talvez o último estágio de uma grande mudança nos paradigmas tecnoeconômicos, marcado pela transição de recursos energéticos não-renováveis para os renováveis e de fontes de energia mecânicas para biológicas, solares e de fissão nuclear a frio. Os sistemas inteligentes, as networks dominam a mente humana. Atualmente existem mais de 100 milhões de computadores no mundo e até a virada do século prevêe-se mais de 1 bilhão.

O conjunto das atividades que compõem o complexo eletroeletrônico - indústria de consumo de bens e serviços de lazer, indústria de consumo de bens e serviços profissionais, automação industrial, indústria de informática e computadores e a indústria de telecomunicações - concentram as principais inovações tecnológicas schumpterianas da terceira revolução industrial.

Máquinas inteligentes, equipadas com reconhecimento de voz e com vocabulário de mais de 30 mil palavras, foram desenvolvidas pela BBN Systems and technologies, de Cambridge-Massachusetts, e a Dragon Systems, de Newton-Massachusetts. No futuro, os cientistas esperam humanizar os robots.

Porém, à medida que a automação penetra em todos os poros da sociedade, os seus efeitos passam a se mostrar no aumento do desemprego. Nos EUA e aqui no Brasil, as maiores vítimas são os afro-americanos, brasileiros ou norte americanos. 
A revolução tecnológica, entre 1940 e 1960, gerou o desemprego em massa nos EUA e no Brasil. Nos EUA, nesse período, mais de 5 milhões de negros do sul agrícola migraram os grandes centros urbanos do norte industrializado. No Brasil, o mesmo aconteceu com milhões de nordestinos e nortistas migrando das regiões agrárias para os grandes centros urbanos do sudeste industrializado.

Surgiu assim uma subclasse urbana e suburbana, isto é, uma parte significativa da população permanentemente desempregada ou subempregada, cuja mão-de-obra não qualificada está excluída do mercado e não tem a devida proteção do governo. A outra parte, formada de profissionais de classe média, quando não são pequenos comerciantes e indústrias ou não desenvolvem atividades de profissionais liberais, tem sido colocado na folha de pagamento do governo.

\subsection{A biotecnologia e o declínio da força de trabalho na agricultura ao ar livre}

Nos EUA, os sistemas especializados estão ajudando a monitorar as pragas e diagnosticar e tratar as ações profiláticas, preventivas e curativas de plantas e animais. Em menos de 20 anos, todas as áreas da bioindústria e da agropecuária estarão sob o controle dos computadores na administração dos agrobusiness. Isso já está acontecendo, também, em algumas fazendas de São Paulo.

A agricultura molecular, bem como as agrotecnologias da informação e da robótica estão mudando a natureza do gerenciamento agrícola substituindo a mão-de-obra humana por robôs e computadores. As biotecnologias de cruzamento genético estão mudando o próprio modo natural, como as plantas e animais são reproduzidos. Logo, os clones de laboratórios de plantas e animais, a exemplo da ovelha Dolly, vão ser reproduzidos em escala comercial.

A engenharia genética, enquanto aplicação da engenharia molecular na manipulação dos genes, está criando novos bioprodutos. As patentes de criaturas fabricadas pelo homem aumentaram nos últimos anos. A vida passou a ser um produto manufaturado. Mais de 200 animais de criação genética esperam a liberação das suas patentes pelo governo do EUA. Os pesquisadores isolaram e clonaram o gene que codifica a toxina da bacteria Bacillus muringiensis (BT) e inocularam na constituição genética do fumo, tomate e algodão e outras plantas. As plantas transgênicas produzem 
toxinas BT que matam as pragas. Por outro lado, o aumento de produtividade que acompanha essas tecnologias, acentua o desemprego estrutural.

\section{Globalização produtiva e o novo exército industrial de reserva}

No presente, além da reestruturação produtiva e da automatização estarem aumentando o stress dos trabalhadores das fábricas e escritórios, os mesmos já não conseguem encontrar empregos de período integral e de estabilidade a longo prazo. Em 1993, nos EUA, 34 milhões de norteamericanos eram trabalhadores contingenciais - trabalhando como temporários em meio período ou por tarefa como freelancers. Esses trabalhadores constituem hoje mais de $25 \%$ da força de trabalho dos EUA.

A atual revolução do mercado de trabalho é no sentido do emprego justin time, tal como os estoques de insumos nas fábricas, as empresas só utilizarão pessoas quando precisem delas. Isto trará graves problemas sobre o bem-estar econômico e a segurança emocional dos trabalhadores. Hoje, os trabalhadores temporários ganham de 20 a $40 \%$ menos do que os fixos fazendo o mesmo trabalho.

A terceirização permite que as empresas reduzam os encargos trabalhistas e ignorem os sindicatos. Nos EUA, um trabalhador que ganhava US $\$ 13$ por hora e desfrutava de um generoso pacote de benefício de uma dada empresa, após demitido, só conseguiu encontrar emprego em uma pequena fábrica fornecedora, a US\$5 por hora, para fazer as mesmas peças que fazia para o seu antigo empregador e sem qualquer benefício social.

\subsection{Morte e violência pela perda do emprego}

O emprego é muito mais que uma medida de renda. Para muitos é a medida essencial de viver e auto merecimento. Estar desempregado, mais do que excluído do mercado, é sentir-se improdutivo e cada vez mais imprestável. Há uma clara correlação entre o desemprego tecnológico e os maiores níveis de depressão, estresse e morbidez psicótica.

Os desempregados inveterados ou os trabalhadores desmotivados, por mais de 6 meses, sentem-se desmoralizados para continuar procurando emprego. Os trabalhadores inveterados têm sintomas patológicos similares. O homicídio é a $3^{\text {a }}$ causa de mortes no ambiente de trabalho. 
Nos EUA, em 1992, 111 mil incidentes de violência no trabalho foram registrados, inclusive com 750 tiros fatais. A morte psicológica segue-se a morte efetiva. Incapazes de administrar sua situação e sentindo-se um peso para a família, para os amigos e para a sociedade, muitos trabalhadores suicidam-se. Este fato, também é verdadeiro no Brasil.

$\mathrm{Na}$ economia high-tech global, nas mãos de empregadores que só visam o lucro abusivo e "governos Pôncio Pilatus", desinteressados pelos problemas do desemprego, os demitidos passam a se considerar descartáveis, excluídos e por fim invisíveis.

\subsection{Globalização e o novo contrato social}

A economia global de alta tecnologia está movendo-se para além do operário. Enquanto as elites empresariais, profissionais e técnicas forem necessárias para administrar a economia formal do futuro, cada vez menos trabalhadores serão necessários para ajudar na produção de bens e serviços. Além disso, ao mesmo tempo em que a necessidade de mão-de-obra está passando por uma redução no setor privado produtivo, o papel do governo está passando também por diminuição semelhante.

A transição de uma economia hard-baseada em matéria, energia e mãode-obra - para uma economia soft - baseada na informação e comunicação vem reduzindo ainda mais a importância do Estado como participante ativo e essencial na garantia dos destinos do mercado. Informações e comunicações, enquanto as matérias-primas da economia global de alta tecnologia, são impermeáveis às fronteiras físicas. Elas invadem espaços físicos nacionais, cruzam linhas geopolíticas e penetram nas camadas sociais mais profundas da vida nacional, sem serem barradas por exércitos, os quais não podem costelas e nem mesmo diminuir o fluxo acelerado da informação e da comunicação através das fronteiras nacionais. O papel geopolítico do Estado está diminuindo tanto quanto o seu papel de empregador e estimulador do mercado. Os acordos internacionais - o acordo do OCM (ex Gatt - Acórdo Geral sobre Comércio e Tarifas), o acordo de Maastrich e os acordos do Mercusul e Nafta - transferem mais poder político da Nação-Estado para as corporações multinacionais.

O papel decrescente, tanto dos sindicatos quanto dos governos centrais, nos assuntos de mercado, forçou uma reconsideração fundamental do contrato social, tal como hoje conhecemos. Privar o corpo político de uma orientação estritamente voltada para o mercado torna-se a tarefa 
prioritária de cada Estado-Nação hoje. As reformas estruturais que atingem o Estado brasileiro, no geral, seguem a corrente neo-liberal.

Como nem o mercado e nem o Estado são capazes de assegurar algumas das necessidades básicas das pessoas, o povo não tem outra alternativa a não ser procurar por si mesmo reestabelecer, mais uma vez, comunidades viáveis para amortecer tanto as forças impessoais do mercado global como das autoridades governamentais, cada vez mais fracas e inoperantes. Muitos recorrerão à economia informal para sobreviver, é o que já está acontecendo. Alguns trocarão trabalho esporádico por comida e haverá um aumento da subclasse urbana.

O aumento do desemprego traz consigo a miséria, a fome e o desespero e com ele a violência urbana e a rural. A tendência, com a redução dos gastos do governo e o aumento da violência social, é a troca das prioridades de assistência social e criação de emprego pela segurança policial e construção de mais prisões, mais isso não resolve o problema. Porém este caminho não é inevitável. Com os empregados tendo mais tempo livre à sua disposição e os desempregados tendo mais tempo ocioso em, suas mãos, a oportunidade existe para aproveitar a mão-de-obra excedente de milhões de pessoas em tarefas construtivas fora dos setores públicos e privados. Os talentos e a solidariedade podem gestar uma nova forma de contrato social

\subsection{O terceiro setor e o novo papel social das organizações voluntárias}

A base para o nascimento de uma terceira força, baseada na vida comunitária, o localismo opondo-se ao globalismo, está emergindo no Brasil e nos EUA. Este terceiro setor, oferece a possibilidade para reformular o contrato social no século XXI. Está baseado em atividades comunitárias, que variam desde serviços sociais, no atendimento à saúde e educação, até a indústria e agricultura comunitária, finanças, pesquisa, artes, religião e advocacia. No Brasil, organizações de serviços comunitários ajudam idosos e deficientes físicos, doentes mentais, jovens desamparados, desabrigados e indigentes. Voluntários reformam apartamentos destruídos e constroem conjuntos habitacionais para a população de baixa renda. Milhares de pessoas passam a ser pais adotivos de velhinhos. Alguns ajudam os jovens a fugir das drogas, outros ajudam as vítimas de estupro e outras violências.

Embora o terceiro setor esteja crescendo, ele costuma ser ignorado pelos políticos, que preferem ver o país com dois planos: o estatal e o 
privado. Entretanto, é o terceiro setor que está assumindo tarefas e realizando serviços - que os outros dois setores não estão dispostos a administrar - e não raro servindo de advogado para defender os interesses ignorados das pessoas abandonadas pelo mercado e pelo governo. Nos EUA, hoje existe 1,5 milhão de organizações sem fins lucrativos cuja principal função é prestar algum serviço ou promover alguma causa: $\mathrm{O}$ projeto do Betinho e o projeto comunidade solidária, são exemplos vivos no Brasil.

Essas organizações, mais do que o setor empresarial, precisam de isenção de impostos e os seus donativos devem ser dedutíveis do imposto. Mesmo porque já foi pago por alguém.

O serviço comunitário, portanto, é uma alternativa revolucionária para as formas tradicionais de trabalho. Ao contrário do trabalho escravo, da servidão e do trabalho assalariado, o trabalho comunitário solidário não é coagido e nem se reduz ao relacionamento fiduciário. Mas, sem dúvida, gera sinergias positivas tanto para o beneficiário quanto para benfeitor. Os efeitos sociais aqui são mais importantes do que os ganhos pecuniários.

Os cientistas sociais franceses, na década de 80 , introduziram o termo economia social não só para diferenciar da economia política, como para esclarecer a distinção entre o terceiro setor e a economia de mercado. A economia social é medida mais em termos dos seus resultados sociais, embora haja ganhos econômicos indiretos: por exemplo, cuidar de pessoas incapacitadas em casa é mais barato do que nos caros hospitais. Socialmente, o terceiro setor tende a ser o mais responsável dos três setores. O terceiro setor, nome cunhado por Jeremy Rifkin, incorpora uma visão alternativa ao ethos utilitário do mercado supremo.

Se o desemprego maciço, de natureza tecnológica, abater-se sobre a sociedade atual, substituindo mão-de-obra por máquinas, então as chances de desenvolver uma sociedade piégas: piedosa e zelosa e uma visão de mundo baseado na transformação do "espírito humano" são improváveis. O rumo mais provável é o de uma convulsão social, violência em escala mundial - a globalização da violência. Porém, se permitirmos que os trabalhadores se beneficiem dos ganhos de produtividade, com semanas de trabalho menores e rendas adequadas, e mais tempo para o lazer, então haverá o bom viver jamais visto na história moderna. Esse tempo livre poderia ser usado para renovar os vínculos comunitários e rejuvenescer a herança democrática conquistada pela classe trabalhadora. 
A globalização do mercado e a redução do papel do Estado significarão que as pessoas serão forçadas a se organizarem em comunidades solidárias para garantirem o futuro. Há, portanto, que se reforçarem os vínculos comunitários e as infra-estruturas locais. Neste sentido, o Estado desempenhará um papel diferente numa Economia Globalizada High Tech: um papel menos vinculado aos interesses do rent seeking e mais alinhado com os interesses da economia social. Moldar uma nova parceria entre o governo e o terceiro setor para reconstruir uma economia social, mais do que uma boa utopia, poderia ajudar a restaurar a vida cívica da nação.

Alimentar pobres, fornecer serviços básicos de assistência à saúde, educar os jovens da nação, construir moradias a preços acessíveis e preservar o meio ambiente, encabeçam a lista das prioridades urgentes dos próximos anos. Para isso, há que se reconstruir uma nova parceria entre governo e comunidades. O Programa Comunidade Solidária, coordenado pela Dra. Ruth Cardoso, do Governo do Presidente Fernando Henrique Cardoso, é um marco no sentido da criação de parcerias do Estado com as comunidades voluntárias. O mesmo se pode dizer do Programa do Betinho.

Nos EUA, o Presidente Clinton deu o primeiro passo nesta direção, com a criação, em abril de 1994, do Non-Profit Liaison Network (Rede de ligação sem fins lucrativos). O governo destinou 25 altos funcionários da administração para trabalhar com o setor não lucrativo em metas comuns. Estes serão responsáveis pela formação de redes de cooperativas entre seus departamentos e agências do governo e organizações do terceiro setor.

Há críticas: os liberais são contra os serviços voluntários e têm uma visão paternalista de elitismo. "A caridade, argumentam, desmerece as vítimas, tornando-as objetos de piedade ao invés de pessoas com valor inerente e direitos inalienáveis, merecedoras de ajuda". Porém os programas sociais, ao contrário, partem do princípio de que cidadãos necessitados têm direito a serviços, não por um ato de caridade, mas pela responsabilidade do governo em promover o bem-estar social como garante a Constituição Federal.

O governo poderia incentivar a maior participação no terceiro setor, pela dedução de imposto por hora de trabalho voluntário dado às organizações legalmente isentas de impostos. Para assegurar uma prestação de contas honesta pelas horas trabalhadas, cada organização isenta de imposto, teria de reportar o número de horas doadas tanto para o governo 
quanto para o voluntário, ao final do ano fiscal, na forma de um formulário padrão de imposto de renda. Ter-se-ia uma forma de salário indireto, um imposto negativo, sob a forma de dedução de impostos sobre a renda pessoal por doação de horas voluntárias.

A dedução de impostos para pessoas que doam parte do seu tempo ocioso às causas voluntárias asseguraria maior envolvimento da sociedade numa variedade de questões sociais que precisam ser encaminhadas já. Embora pudesse haver uma perda de receita tributária, esta poderia ser mais que compensada pela menor necessidade de programas governamentais caros e ineficientes. A melhoria da qualidade de vida de milhões de pessoas menos favorecidas poderia se reverter na forma de melhores oportunidades de emprego e maior poder de compra e com isso poder-se-ia elevar a receita tributária disponível a cada nível de governo.

Alguns poderiam argumentar que a concessão de dedução de impostos por hora voluntárias e poderia minar o "espírito voluntário". Não se descarta essa possibilidade, porém as chances disso ocorrer são remotas. De fato, afinal, contribuições de caridade dedutíveis de impostos parecem ter encorajado mais os espíritos filantrópicos, e tudo indica que a criação de um salário indireto apenas encorajaria aqueles que voluntariamente querem dar mais de seu tempo à economia social, ao invés de trabalhar horas extras em atividade monotônicas, em um segundo emprego, para equilibrar o orçamento ou ficar ociosamente sentado na frente da televisão todas as noites.

Para evitar que a sociedade se desintegre em milhares de iniciativas locais isoladas e sem uma finalidade e uma direção nacional coerente, os governos precisarão alavancar o setor voluntário com incentivos ao trabalho para manter um senso de identidade e de vontade política nacional tendo em vista a construção de uma nova economia social. Além disso, o governo poderia pensar no salário social por serviços comunitários como alternativa ao desgastado seguro-desemprego. O pagamento de um salário social, como alternativa a pagamentos previdenciários e outros benefícios sociais, para milhões de pessoas permanentemente desempregadas, mas dispostas a serem retreinadas e empregadas em trabalhos no terceiro setor - a exemplo do programa de renda mínima de algumas prefeituras brasileiras - é uma alternativa merecedora de atenção. O governo também deveria conceder isenções fiscais à organizações sem fins lucrativos que quisessem ajudar a recrutar e treinar os trabalhadores desempregados para cargos em suas organizações no terceiro setor. Isso ajudaria não apenas os 
beneficiários, mas também as comunidades onde o trabalho fosse empregado.

Um salário social adequado daria a milhões de pessoas desempregadas, trabalhando nessas organizações comunitárias, a oportunidade de ajudarem a si próprios. Talvez esses programas sejam uma alternativa aos programas de obras públicas e de trabalho servil na economia formal, já que os primeiros reestabelecem laços solidários nas comunidades locais.

Além de se proporcionar um salário social para os cidadãos mais pobres, está idéia pode estender-se a trabalhadores especializados e até mesmo a cargos administrativos e trabalhadores profissionais cujo trabalho foi desqualificado pela globalização do mercado. Um terceiro setor viável requer uma variedade de habilidades que vão desde os conhecimentos mínimos até as sofisticadas técnicas de gerência fundadas no principio da qualidade total. Poder-se-ia ter, em certos casos, um mix de trabalhadores especializados e não especializados atuando junto às atividades comunitárias.

Até mesmo o Pai do Liberalismo Moderno - Milton Friedman defendeu essa proposta na forma de um imposto negativo sobre a renda. Ele argumentava que seria muito melhor dar aos pobres uma renda anual mínima garantida do que continuar financiando o labirinto e sorvedouro de programas sociais burocráticos que serviam apenas para perpetuar a pobreza, ao invés de aliviá-la, e alimentar os burocratas e hospitais. É claro que há um exagero nisso. Porém, pode-se esperar que os beneficiários possam complementar esses incentivos ao trabalho, com o seu próprio trabalho. O subsídio deveria, entretanto, diminuir moderadamente à medida que a receita pessoal dos beneficiários subisse e se tornasse estável e perene. Isto não seria novidade, visto que as medidas de auxílio e previdência social já constituem uma renda governamental anual garantida em substância, embora não nominal. Ou seja, trocando em miúdos, não se pode penalizar a produtividade das pessoas desempregadas que complementam sua renda com outras atividades, pelo menos enquanto não encontram um novo emprego perene.

Nos EUA, se uma pessoa que recebe auxílio-desemprego ganha um dólar por algum trabalho prestado, e se declara isso em obediência a lei, seu salário desemprego é reduzido também em um dólar. O efeito é penalizar o trabalho, ou a honestidade, ou ambos, não sei. Hoje o programa de renda garantida voltou a ser discutido nos EUA, porém diferentemente dos anos anteriores, a renda social deve ficar vinculada à concordância do 
desempregado em realizar serviço comunitário no terceiro setor - na verdade, promovendo o conceito de um salário social em troca de trabalho real na economia social.

A experiência francesa é mais interessante, pois vincula a renda social mínima à aceitação pelo beneficiário de trabalho que seja social ou culturalmente útil à comunidade ou a participação dele em cursos de retreinamento ou de reintegração na vida ativa. A idéia de proporcionar uma renda mínima garantida em troca da concordância em realizar trabalho comunitário tende a ser adotada nos países que querem administrar a questão do desemprego tecnológico e prover tanto renda quanto trabalho meritório na ausência do emprego formal. Os custos desses programas comunitários são pequenos em relação aos burocráticos e seus retornos econômicos superam em muito as despesas.

\section{Paradoxos do emprego numa economia globalizada}

Existem muitos paradoxos neste mundo globalizado. Porém John Naisbitt, o mesmo escritor do best-seller $\mathrm{n}^{\circ} 1$ na lista do New York Times - megatendências - afirma no seu outro livro, o Paradoxo Global, que o principal paradoxo da globalização é: "Quanto maior a economia mundial, mais poderoso são os seus protagonistas menores".

Ele refere-se principalmente ao empreendedor, ao homem de negócios. As grandes empresas, caso pretendam sobreviver, precisam ser fragmentadas em redes regionalizadas nos macromercados supra nacionais através de múltiplas confederações de empresas pequenas, autônomas e empreendedoras.

Enquanto isso, as economias de escala tendem a ser substituídas pelas economias de escopo. O termo downsiz̨ing (que significa redução, declínio), reengenharia, organizações em redes ou empresa virtual, qualquer dessas denominações, explicam o mesmo fenômeno: As empresas precisam desmantelar as burocracias, se desejam sobreviver.

A ABB Asea Brown Boveri, o maior grupo atual de engenharia elétrica, com receita que excede a US\$ 30 bilhões por ano, tem 1200 empresas. Cada empresa possui 200 empregados em média. Trata-se de uma empresa global. Como diz o seu presidente Percy Barnevik: crescemos o tempo todo, mas também diminuímos o tempo todo. Ou seja, no processo de desconstrução, o quadro funcional da empresa, em Zurique, foi reduzido de 4.000 mil para menos de 200 pessoas. Nada menos de $90 \%$ das vendas da empresa suíço-sueca vêm de fora dos países-sede. 
Eles são uma empresa global porque tem uma coleção de empresas locais, pequenas e médias, como uma coordenação global intensa - uma holding. Num mundo globalizado, as empresas são conglomerados multisetoriais ou multidivisionais, e não mais unitárias, que se organizam em redes e realizam uma hierarquia que permite negócios intra-firmas e com o mercado.

No capitalismo do futuro, o capital físico ainda será necessário. Porém, o conhecimento, a informação e organização de novas tecnologias serão os novos ingredientes estratégicos. Isso leva a uma pergunta: o que acontecerá com o capitalismo quando se esgotarem as fontes estratégicas de sua própria vantagem competitiva em relação a sistemas econômicos alternativos?

Se as empresas globais - nas quais a habilidade, a formação escolar e o conhecimento do capital humano são as fontes dominantes da vantagem estratégica - forem examinadas, ver-se-á que elas não guardam mais nada com as empresas tradicionais. Elas são mais flexíveis e agressivas no mundo dos negócios. Quando sai um funcionário habilidoso, as idéias e tecnologias únicas da empresa vão com ele para o novo empregador: este é o poder cerebral da economia global. A comunicação entre ativos torna-se mais importante do que a concentração de ativos numa sociedade comandada por cérebros e computadores.

O capital humano difere do capital físico em três aspectos: “(1) o capital humano não pode ser possuído; logo os capitalistas não investem naquilo que não podem possuir; (2) os investimentos de capital humano em geral requerem um horizonte de tempo muito mais longo que aquele permitido pelo capitalismo; (3) os investimentos de conhecimento que precisam ser feitos para a geração de indústrias de poder celebral, precisam ser feitos em ambientes estranhos a orientação individualista do capitalismo". Segundo estimativas, nos EUA, 16 anos de ensino de alta qualidade representam US $\$ 250.000$ por filho. Os riscos desse investimento em capital humano não se pagar, são altos.

O capitalismo é um sistema cuja maior força está em sua capacidade de atender diferentes preferências individuais e desenvolver as forças produtivas. Sua fraqueza é sua miopia temporal. Ele tem um horizonte de tempo intrinsecamente curto não só porque no longo prazo as expectativas dos seus agentes econômicos são radicalmente incertas, como devido a necessidade que têm as empresas de girar o capital num tempo de rotação cada vez menor. 
Com efeito, simplesmente não se tem obrigações sociais no capitalismo pela via do mercado - a mão invisível. Quando o governo a mão visível - assume os investimentos em capital social básico - infrainstrutora econômico e infra-estrutura social - apesar de essenciais, eles não são reconhecidos socialmente pelos capitalistas que reclamam de pagar impostos.

No capitalismo, não há uma análise precisa do futuro distante. Ele é incerto no sentido de Keynes. No momento atual, o rompimento do contrato social é resultado do choque da economia global e das tecnologias modernas. Talvez o capitalismo contemporâneo esteja construindo um novo contrato social cuja base é dada pela empresa global que não aceita garantir o emprego vitalício, com salários crescentes, mas está disposta a garantir, pelo menos enquanto o trabalhador fizer parte da sua equipe, o investimento, forçada pela concorrência, no desenvolvimento de habilidades do capital humano por toda a sua carreira na empresa. Essas novas habilidades adquiridas poderão elevar seu salário na empresa que investiu no aumento da sua produtividade ou ser usada em outras empresas.

O emprego vitalício poderá, no futuro, ser substituído pela empregabilidade vitalícia. Um novo padrão de contrato social como este exigirá mudanças nas políticas tradicionais de formação de recursos humanos, mas não há tempo para tratar desse tema aqui. De qualquer modo, o capitalismo terá que criar novos valores sociais e novas instituições que permitam um novo equilíbrio estratégico entre o estatal, o privado e o comunitário.

\section{Conclusão}

Neste final de século, a tecnologia e a ideologia sinalizam um divórcio. Paradoxalmente, quando o capitalismo se encontra sem concorrentes sociais - comunismo, o fascismo e as ditaduras militares poderosas - terá que passar por uma profunda metamorfose.

É fácil as pessoas ficarem desencorajadas e se tornarem pessimistas, quando vêem o que deve ser feito, e se angustiarem com o ritmo lento das mudanças sociais. As ondas perdem todos os dias para o rochedo, porém a longo prazo elas vencem os rochedos". A esperança por dias melhores ainda não morreu e nem o sonho por uma sociedade democraticamente igualitária acabou, a persistência e a disposição de muita gente boa para mudar a sociedade não pode desvanecer. A jornada para o desconhecido mundo global, tal como Colombo, já começou. 


\section{Bibliografia consultada}

ALTVATER, Elmar. O preço da riqueza: pilhagem ambiental e a nova (des) ordem mundial. São Paulo, Universidade Estadual Paulista, 1995.

ARAÚJO JR., José Tavares de. Concorrência, competitividade e política econômica. In: Renato Baumann (Org.). O Brasil e a economia global. São Paulo, Campus, 1996.

BAUMANN, Renato. Uma visão econômica da globalização. In: Renato Baumann (Org.). O Brasil e a economia global. São Paulo, Campus, 1996.

BIELSCHOWSKY, Ricardo \& Stumpo, Giovanni. A internacionalização da indústria brasileira: número e reflexões depois de alguns anos de abertura. In: Renato Baumann (Org.). O Brasil e a economia global. São Paulo, Campus, 1996.

CARVALHO, David Ferreira. Crise de hegemonia e globalização na nova ordem mundial. Papers do NAEA 31. Belém, NAEA/UFPA, novo 1994.

. Globalização, Mercados Especulativos e Crescimento Econômico Mundial em Marcha Lenta. Papers NAEA 61. Belém, NAEA/UFPA, nov. 1997.

. Globalização, estabilização e finanças públicas na economia brasileira.

Revista do Banco do Nordeste. Fortaleza, BN/ANPEC, Edição Especial, jun-set, 1997.

COUTINHO, Luciano. A terceira revolução industrial. Economia e Sociedade. Campinas, n. 1, p. 69-88, ago. 1992.

CANUTO. Abertura comercial, estrutura produtiva e crescimento econômico. Economia Sociedade. Campinas, IE/UNICAMP, p. 21-36, dez. 1994.

CANO, Wilson. Reflexões sobre o Brasil e a nova (des) ordem internacional. Campinas, UNICAMP /FAPESP, 1994.

DAUBLER, Wolfgang. Relações de Trabalho no Final do Século XX. In: O mundo do trabalho: crise e mudança no final do século. São Paulo, Página Aberta, 1994.

FREITAS, Carlos Eduardo de. Liberdade Cambial. In: Renato Baumann (Org.). O Brasil e a economia global. São Paulo, Campus, 1996.

FUKUYAMA, Francis. Confiança: Valores Sociais \& Criação de Prosperidade. Lisboa, gradiva, 1996.

. The borddess world. New York, Harper Collins, 1990.

GONÇALVES, Reinaldo. Globalização financeira, liberalização cambial e vulnerabilidade externa da economia brasileira. In: Renato Baumann (Org.). O Brasil e a economia global. São Paulo, Campus, 1996.

GUTTMANN, R. How credit-money shapes the economy: the united states in a global system. New York, M. E. Sharpe, 1993.

HOBSBAWM, Eric. Era dos extremos: o breve século XX, 1914-1991. São Paulo, Companhia das Letras, 1995. 
LEITE, Marcia de Paula. Reestruturação produtiva, novas tecnologias e novas formas de gestão da mão-de-obra. In: O Mundo do Trabalho: Crise e Mudança no Final do Século. São Paulo, Página Aberta, 1994.

MATTOSO, José Eduardo. O novo e inseguro mundo do trabalho nos países avançados. In: $\mathrm{O}$ mundo do trabalho: crise e mudança no final do século. São Paulo, Página Aberta, 1994.

MICHALET, Charles-Albert. O capitalismo mundial. Rio de Janeiro, Paz e Terra, 1983.

MINSKY, Hyman P. Integração financeira e política monetária. Economia e Sociedade. Campinas, IE/UNICAMP, p. 21-36, dez, 1994.

NAISBITT, John. Paradoxo global: quanto maior a economia mundial, mais poderosos são os seus protagonistas menores: nações, empresas e indivíduos. Rio de Janeiro, Campus, 1994.

OHMAE, Keinichi. O fim do estado nação: a ascensão das economias regionais. Rio de Janeiro, Campus, 1996.

PIORE, M. J. The Technological foundations of dualism and discontinuity. In: Berger, $\mathrm{S}$ and Piore, M. J. (eds). Dualism and Discontinuity in Industrial Societies. Cambridge, Cambridge University Press, 1980.

PIORE, M and Sabel, C. F. The second industrial divide: possibilities for prosperity. New York, Basic Books, 1984.

PORTE, M. E. The Competitive advantage of nations. London, Macmillan, 1990.

RIFKIN, Jeremy. Fim dos Empregos: O declínio inevitável dos níveis dos empregos e a redução da força global de trabalho. São Paulo, Makron, 1995.

TAVARES, Maria da Conceição. Ajuste e reestruturação nos países centrais. Economia e Sociedade. Campinas, IE/UNICAMP, n. 8, p. 143.-182, jun. 1997

Ajuste e Reestruturação nos Países Centrais: A modernização conservadora. In: Tavares, Maria da Conceição \& Fiori, José Luís. Desajuste global e modernização conservadora. Rio de Janeiro, Paz e Terra, 1993.

. As políticas de ajustes no Brasil: os limites da resistência: a modernização conservadora. In: Tavares, Maria da Conceição \& Fiori, José Luís. Desajuste global e modernização conservadora. Rio de Janeiro, Paz e Terra, 1993.

TAVARES, Maria da Conceição \& Melin, Luiz Eduardo. A Desordem Globalizada e a Nova Dependência. Revista ANPEC, n² 2. Rio de Janeiro, Anpec, ago, 1997.

TRUROW, Lester C. O futuro do capitalismo: como as forças econômicas de hoje moldam o mundo de amanhã. Rio de Janeiro, Rocco, 1997. 


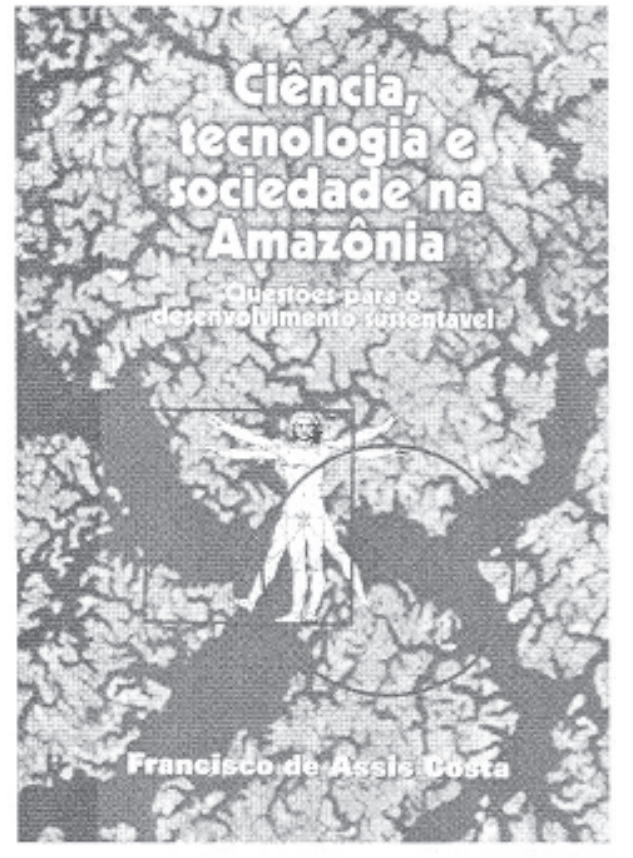

\section{Ciência, Tecnologia e Sociedade \\ na Amazônia: questões para o desenvolvimento sustentável Francisco de Assis Costa}

(1998)

O autor reúne nesta obra uma importante discussão e análise do processo de desenvolvimento da ciência e da tecnologia na Amazônia brasileira. Tão abrangente é este estudo que muitos de seus resultados e conclusões podem aplicar-se ao resto do território dos outros países que compartilham a bacia. Mais ainda, poderiam servir de base para a adoção de decisões regionais sobre o assunto. Discussões sobre assimetria, instabilidade e descontinuidade das instituições de ciência e tecnologia na Amazônia também integram o corpo deste trabalho, assim como levantamento de questões e sugestões para o desenvolvimento sustentável na Amazônia.

\section{Negros do Trombetas: guardiães de matas e rios Rosa Acevedo e Edna Castro (1998 - 2a Edição)}

As autoras trilharam as ações de resistência de um grupo étnico identificado enquanto formado por remanescentes de quilombos. Esses habitantes da região do Trombetas, chamados Filhos do Rio, fizeram do movimento de circulação das águas o pulso de sua existência e da memória social.

A liberdade vigiada, em contínuo sobressalto, e o freio da natureza, os obrigaram a buscar outra alternativa: viver a liberdade condicionada, abaixo da última cachoeira, no rio manso, para desenvolver a vida material e recriar os símbolos de sua identidade atua!. Com este estudo os autores pretendem contribuir à compreensão da dimensão política das lutas sociais que envolvem conflitos étnicos e territorialidades na Amazônia, os impactos dos grandes projetos minerais e hidrelétricos e as novas formas de exclusão que se ancoram no discurso ideológico da preservação ambienta!.

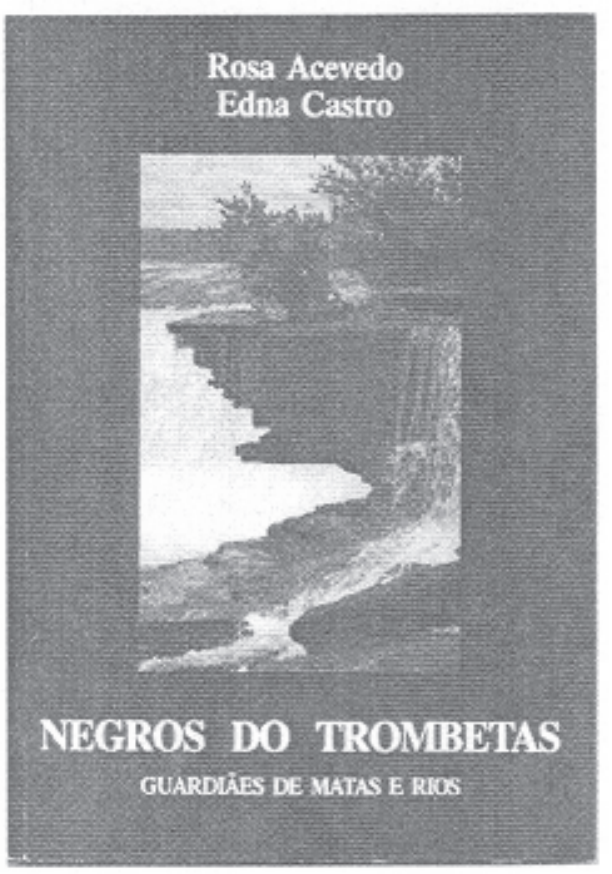

